\title{
Determination of Iodides from Groundwater and Surface Water using an Optimized Ion Chromatographic Method
}

\section{VALERIU ROBERT BADESCU, OLGA TIRON, GABRIELA GEANINA VASILE*, LAURENTIU RAZVAN DINU}

National Research and Development Institute for Industrial Ecology ECOIND, 71-73 Drumul Podul Dambovitei Str., 060652, Bucharest, Romania

Abstract: The research aimed to provide an optimized method for the determination of iodides concentration in groundwater and surface water sources using ion chromatography technique. The analyses were conducted by using a conductivity detector, with a $35 \mathrm{mM} \mathrm{KOH} \mathrm{mobile} \mathrm{phase,} \mathrm{at} \mathrm{a} \mathrm{flow}$ rate of $1 \mathrm{~mL} / \mathrm{min}$, the temperature in the detector chamber and the intensity of the suppressor current being set at $35^{\circ} \mathrm{C}$ and $87 \mathrm{~mA}$, respectively. The interferences given by other ions were also investigated, and the performance parameters were determined such as detection limit, quantification limit, accuracy, and recovery.

Keywords: iodides, ion chromatography, water sources

\section{Introduction}

Iodine is an essential element required for the synthesis of thyroid hormones. Unfortunately, about two billion people are facing iodine deficiency, which is responsible for multiple disorders [1] causing serious health problems mainly at infants and young children with long-term consequences [2]. On the other hand, excess iodine content in the human diet can severely affect the hormone synthesis activity leading to goiter and hypothyroidism diseases $[3,4]$. Besides that, research in the field underlined that providing iodine to the persons who have had a sufficient or excess concentration of this element increases the incidence of autoimmune diseases [5].

In water sources, iodine is predominantly found as iodide $\left(\mathrm{I}^{-}\right)$or iodate $\left(\mathrm{IO}^{-3}\right)$ [6]. Other forms in which iodine is present would be the periodate $\left(\mathrm{IO}^{-4}\right)$, hypoiodite $\left(\mathrm{IO}^{-}\right)$, methyl iodide $\left(\mathrm{CH}_{3} \mathrm{I}\right)$, ethyl iodide $\left(\mathrm{C}_{2} \mathrm{H}_{5} \mathrm{I}\right)$, propyl iodide $\left(\mathrm{C}_{3} \mathrm{H}_{7} \mathrm{I}\right)$, butyl iodide $\left(\mathrm{C}_{4} \mathrm{H}_{9} \mathrm{I}\right)$, and methylene iodide bromide $\left(\mathrm{CH}_{2} \mathrm{Br}\right)$ [7].

It is worth to point out that organic and inorganic iodine species found in water sources can react with disinfection products and by-products (such as ozone, chlorine, and chloramine) found during potabilization flow, resulting iodinated disinfection by-products representing a potential carcinogenic source as they print genotoxic and cytotoxic properties to mammary cells [8].

The role of iodine in human health has outlined the need for the development of more sensitive analytical techniques for its investigation. Currently, advanced analytical techniques are used, methods' sensibility reaching ultra-trace level. Certain methods have become routine techniques for traceability in clinical or analytical laboratories. Other methods have been proposed for iodide and iodate anions analysis in aqueous solutions. such as catalytic methods (for $0.1 \mu \mathrm{g} / \mathrm{L}$ detection limit) [9], ionchromatographic (IC) methods in different variants (as for example IC and exchange capacity controllable columns and column-switching technique (for $5.7 \mu \mathrm{g} / \mathrm{L}$ detection limit)) [10], IC coupled with an ultraviolet detector (for $9.45 \mathrm{nM}$ detection limit) [11]. IC techniques are also used for the analysis of other inorganic ions (chloride, bromide, fluoride, etc.) [12-14].

Chromatographic methods are specially used for the determination of iodine species when coupled with Inductively Coupled Plasma Mass Spectrometry (ICP-MS) (for $0.010 \mu \mathrm{g} / \mathrm{L}$ detection limit) [15]. An ICP-MS analysis technology for simultaneous determination of bromine and iodine in high-salinity water was also developed, a low detection limit of $0.015 \mu \mathrm{g} / \mathrm{L}$ being obtained [16].

\footnotetext{
*email: gabriela.vasile@incdecoind.ro
} 
In the literature, indirect iodine determination methods are also presented, for instance: atomic absorption methods, with a detection limit of $2.75 \mu \mathrm{g} / \mathrm{L}$ [17] or Inductively Coupled Plasma Atomic Emission Spectrometry Methods (ICP-EOS) $(2 \mu \mathrm{g} / \mathrm{L}$ detection limit) [18].

Besides, chemical vapor generation, pneumatic nebulization, and ICP-EOS methods could be coupled to improve the sensibility of the analyses, obtained results indicating $0.02 \mu \mathrm{g} / \mathrm{L}$ detection limit for iodide determination, this technology is used mainly for investigations conducted on seawater and spring water sources [19].

The paper presents an ion-chromatographic technique for the analysis of iodide anions in surface water and groundwater sources. The study is addressing for the establishment of (1) the optimal parameters for element investigation by using ion-chromatograph coupled with a conductivity detector, (2) the performance parameters of the proposed method (detection and quantification limits, working range, linearity, precision, recovery) as well as covers (3) the validation tests for method's selectivity (interference tests).

\section{Materials and methods}

\subsection{Reagents and materials}

Anion separation column type AS20 4 × $250 \mathrm{~mm}$; Preguard column type AG20 4 × $50 \mathrm{~mm}$; Potassium hydroxide $(\mathrm{KOH})$ pellets $85 \%$ (Scharlau); Certified Reference Material (CRM) Iodide standard for IC $1000 \mathrm{mg} / \mathrm{L}$, Trace CERT; Potassium iodide puriss (KI) 99.88\% (Sigma Aldrich); Ultrapure water type ASTM 1.

CRM $1000 \mathrm{mg} / \mathrm{L}$ Iodide, Trace CERT type, was used for the calibration curve, the following standard solutions being prepared: 2, 4, 6, 8, and $10 \mathrm{mg} / \mathrm{L}$, respectively.

Results assessment was performed with potassium iodide reagent.

\subsection{Equipment}

Ion Chromatograph ICS-3000 (Dyonex, USA) with Dyonex AS-AP Autosampler.

Ultrapure water system ELX Technology Inside Milli-Q (Millipore).

\subsection{Optimization tests of the operational parameters of the method}

The selected operational column allows a good separation of the iodide anion, the retention time being about 11 minutes. For this reason and as also taking into consideration that studies reported at this stage were performed on synthetic solutions to avoid any possible interferences with other anions, the retention period was increased to $15 \mathrm{~min}$.

Since the used detector was of the electrical conductivity type, the volume of the injection loop was chosen to be $250 \mu \mathrm{L}$ that one may maximize signal strength from the detector.

To ensure optimal conditions for the calibration curve, a preliminary study was conducted for investigating the influence of the operational parameters on the detector's signal value.

Hence, the study required the testing of the various (1) eluent concentrations, the parameter being also known as the 'mobile phase'. As long as the electrical conductivity depends on the temperature's value, the investigation of the (2) optimum temperature required in the detector and column compartments was also considered. (3) Mobile phase flow rate was another researched indicator. Electrochemical type of the suppressor required to set a (4) current intensity for which signal suppression is maximal. By electrochemical process, the anion suppressor provides $\mathrm{H}^{+}$necessary to suppress $\mathrm{HO}^{-}$ion, in this way ions resulting from water dissociation being combined, the process leading to a decrease of the electrical conductivity and background noise.

\subsection{In-house validation experiments}

The experimental tests required for in-house validation of the method involved the assessment of the following performance parameters: detection limit (LOD), quantification limit (LOQ), precision tests (reproducibility, intermediate precision), linearity (parameters of the calibration curve, 
homogeneity of dispersions test), recovery. The details related to the conducted experimental analyzes are presented in Table 1.

Table 1. Experimental tests followed for in-house validation of the method.

$\begin{array}{cc}\text { LOD, LOQ } & 0.7 \mathrm{mg} / \mathrm{L}, 10 \text { determinations } \\ \text { Calibration curve } & 2 \mathrm{mg} / \mathrm{L}, 4 \mathrm{mg} / \mathrm{L}, 6 \mathrm{mg} / \mathrm{L}, 8 \mathrm{mg} / \mathrm{L}, 10 \mathrm{mg} / \mathrm{L} \\ \text { Homogeneity of dispersions test } & 2 \mathrm{mg} / \mathrm{L} \text { and } 10 \mathrm{mg} / \mathrm{L}, 10 \text { determinations for each concentration } \\ \text { Reproducibility } & 6 \mathrm{mg} / \mathrm{L}, 9 \text { determinations } \\ \text { Intermediate precision } & 6 \mathrm{mg} / \mathrm{L}, 18 \text { analysis } \\ \text { Recovery } & \text { Drinking water enriched with } 4 \mathrm{mg} / \mathrm{L}, 8 \text { determinations }\end{array}$

\subsection{Interference studies}

To identify the susceptible anions that could influence the results of determinations for the studied analyte, type of column, and implicitly the anions having affinity to this type and their abundance and frequency in the studied matrices (groundwater, surface water) were taken into consideration.

The selectivity of the proposed method was achieved by testing the interference given by fluoride, chloride, sulfate, thiocyanate, thiosulfate, and carbonate anions. For each anion, three concentrations were tested (for the same iodide concentration) and the recovery yield for iodide was calculating.

\subsection{Real samples analyze}

The research was conducted on 40 water samples (underground water, surface, spring, and geothermal water sources), each analysis being performed in duplicate.

\section{Results and discussions}

As it was mentioned above, for achieving a maximum intensity of the signal for iodide determination with IC method, optimization of the operational parameters which influence the signal's value is requiring, being tested: eluent concentration, the flow rate of the mobile phase, the temperature in the detector chamber, and intensity of the suppressor current.

\subsection{Optimization of the eluent concentration $(\mathrm{KOH})$}

Different values of eluent concentration (in a range of 3.5-50 mM KOH) were tested for $10 \mathrm{mg} / \mathrm{L}$ iodide concentration, obtained results being shown in Figure 1. As it could be noticed, the lowest concentration of the purifying phase conducting a low signal $(0.55 \mu \mathrm{S})$, a flattened shape of the peak being obtained (Figure 2). The highest signal of the conductivity detector was achieved at $35 \mathrm{mM}$ $\mathrm{KOH}$, in this case, the detector response being $3.42 \mu \mathrm{S}$ (Figure 3 ).

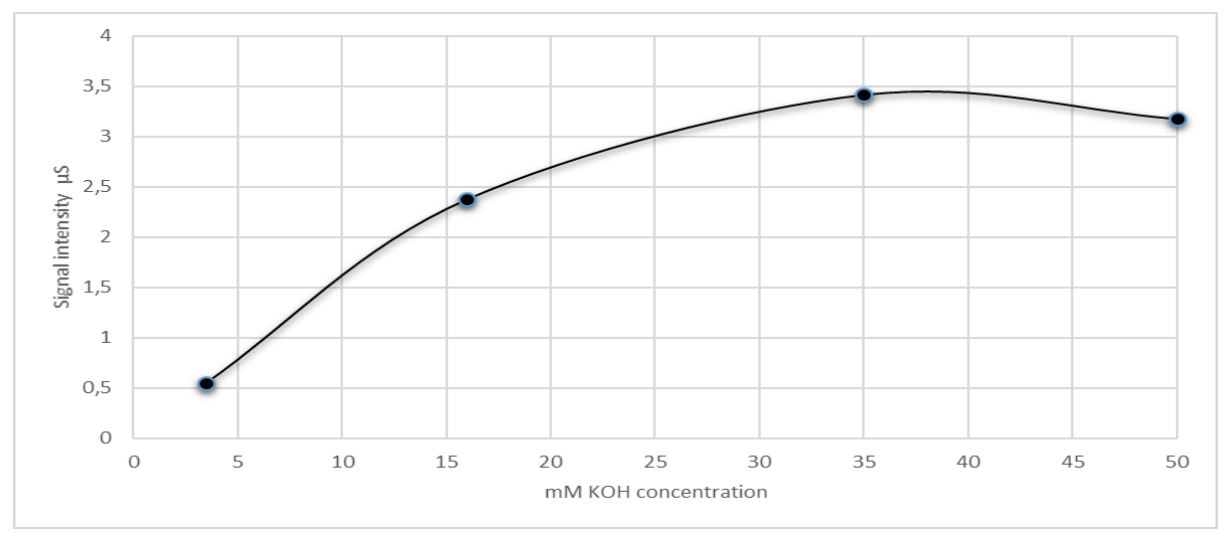

Figure 1. Signal evolution according to $\mathrm{KOH}$ mobile phase concentration 


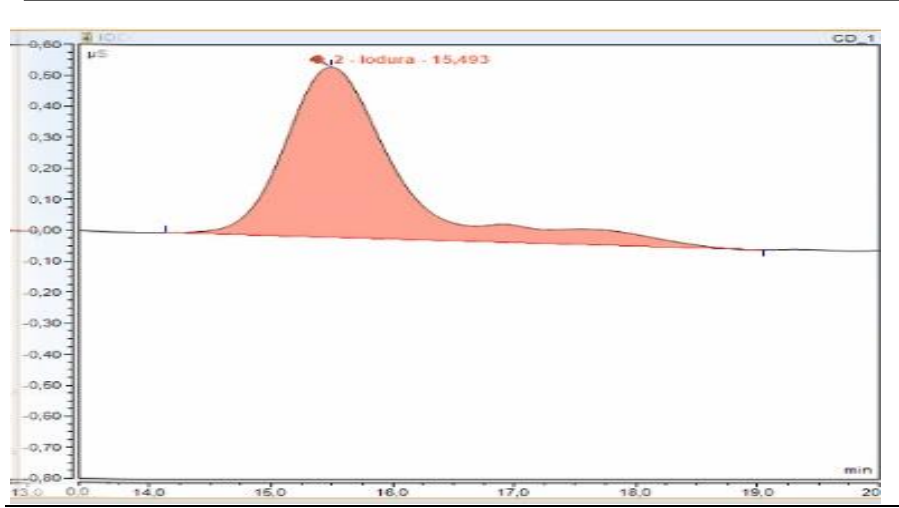

Figure 2. Chromatogram of iodide obtained at $3.5 \mathrm{mM} \mathrm{KOH}$ eluent concentration

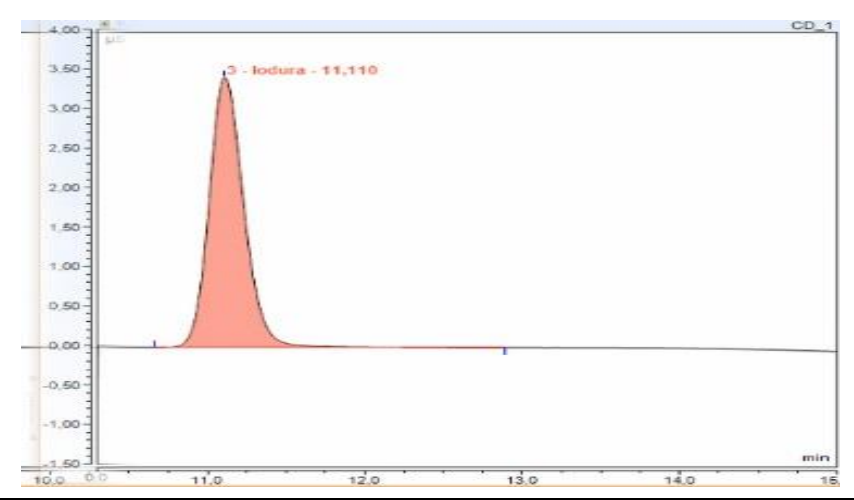

Figure 3. Chromatogram of iodide obtained at $35 \mathrm{mM} \mathrm{KOH}$ eluent concentration

\subsection{The optimal flow rate of the mobile phase}

Flow rate represents another important parameter to be tested whose value influences the amount of eluent in the column. As a result, the tests were performed at a different flow rate $(0.6,0.8,1$, and $1.5 \mathrm{~mL} / \mathrm{min}$ ) for optimizing the response and implicitly for obtaining a maximum signal. In this case, all tests were performed on a synthetic water sample containing $10 \mathrm{mg} / \mathrm{L}$ iodide to ensure a strong signal.

A flow rate of $0.6 \mathrm{~mL} / \mathrm{min}$ has a $0.94 \mu \mathrm{S}$ signal, the peak of the shape being highly distorted. As it could be noticed in Figure 4, the maximum signal response $(3.825 \mu \mathrm{S})$ was recorded at a flow rate of $1.0 \mathrm{~mL} / \mathrm{min}$.

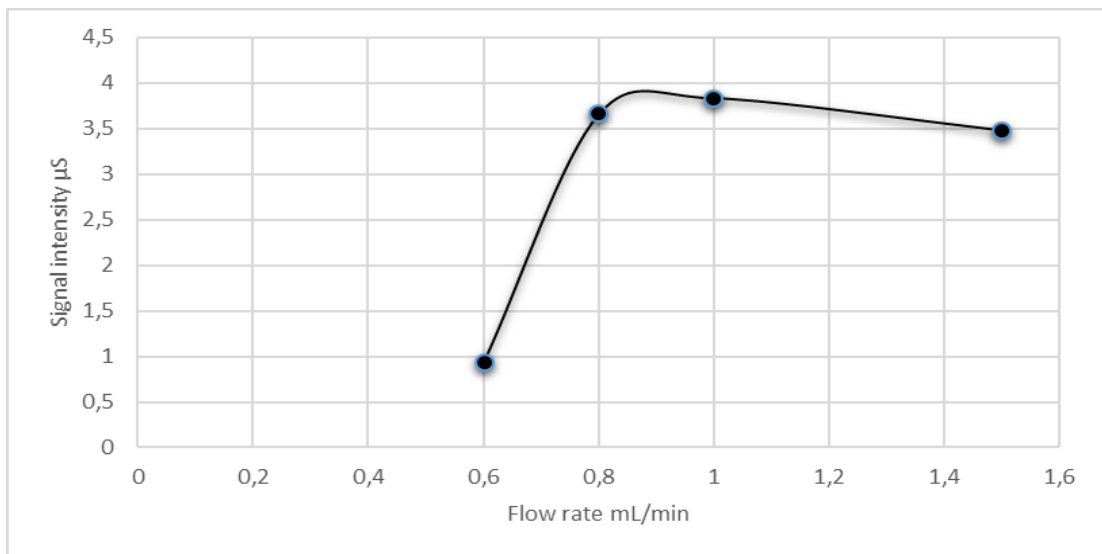

Figure 4. Signal evolution according to the mobile phase flow rate

\subsection{Setting the optimum temperature}

Another important parameter for the optimal setting of the ion chromatograph detector is the temperature set in the detector enclosure and column compartment. Since the conductivity depends on the temperature's value, the detector and column rooms are thermostated in to ensure measurements at a constant temperature. The experimental tests were performed at $25,30,35$, and $40^{\circ} \mathrm{C}$, respectively, by using a $10 \mathrm{mg} / \mathrm{L}$ iodide solution.

For a temperature set at $25^{\circ} \mathrm{C}$ in the soft program of IC, no response from the detector was obtained corresponding to the iodide retention time chose for the separation column. Since no signal was recorded at this temperature, the parameter's value was increased up to $30^{\circ} \mathrm{C}$, a signal of $2.73 \mu \mathrm{S}$ being registered. The highest value of conductivity was obtained at $35^{\circ} \mathrm{C}$, corresponding to a peak height of $3.48 \mu \mathrm{S}$ (Figure 5). 


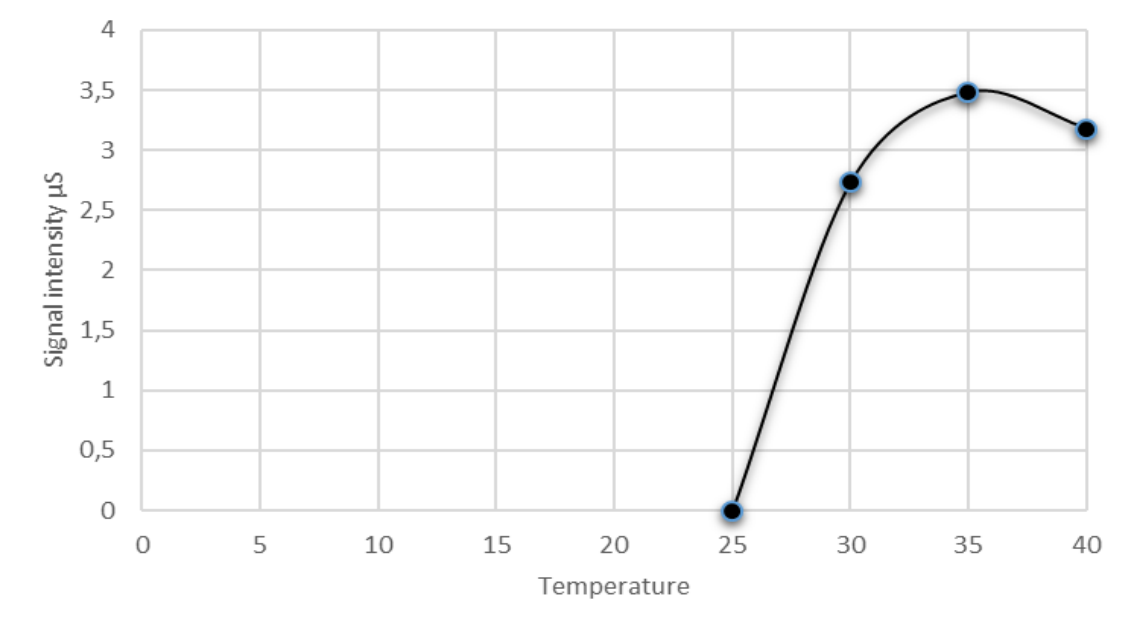

Figure 5. Signal evolution according to the temperature value

\subsection{The optimum intensity of the suppressor current}

Since the suppressor reduces the electrical conductivity of the eluent and implicitly the background, it is very important to set it to the optimal parameter. The electrolytic process takes place in the suppressor, and according to Faraday's electrolysis law, the current intensity is directly proportional to the mass deposited on the electrodes. The experimental tests have been performed at intensities of 50,70,87, and $100 \mathrm{~mA}$, respectively.

At a $50 \mathrm{~mA}$ suppressor current, no signal of the analyte retention time was detected. As a result, the suppressor current was increased progressively, the highest signal $(3.45 \mu \mathrm{S})$ being obtained at $87 \mathrm{~mA}$. The evolution of the detector response according to the current intensity is shown in Figure 6.

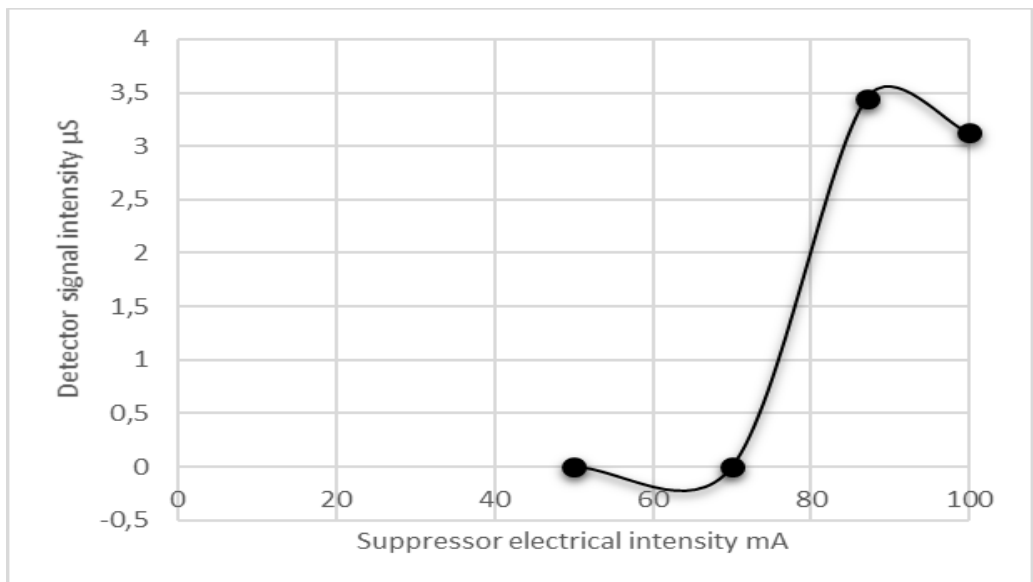

Figure 6. The response of the detector according to electrical intensity

The final settings performed after the optimization phase are presented in Table 2 .

Table 2. Optimized parameters for iodide determination

\begin{tabular}{c|cccc}
\hline Parameter & $\begin{array}{c}\text { Eluent } \\
\text { concentration }\end{array}$ & $\begin{array}{c}\text { Flow rate of } \\
\text { mobile phase }\end{array}$ & $\begin{array}{c}\text { Temperature in } \\
\text { detector chamber }\end{array}$ & $\begin{array}{c}\text { Intensity of the } \\
\text { suppressor current }\end{array}$ \\
\hline Value & $35 \mathrm{mM} \mathrm{KOH}$ & $1 \mathrm{~mL} / \mathrm{min}$ & $35^{\circ} \mathrm{C}$ & $87 \mathrm{~mA}$ \\
\hline
\end{tabular}




\subsection{In-house validation experiments}

In the first, the validation test followed the linearity property check, meaning the selection of the working field adequate to the iodine concentrations from underground water sources. The calibration curve involved iodine concentrations ranging between 2 and $10 \mathrm{mg} / \mathrm{L}$ (Figure 7). A homogeneity test of the dispersions for the lowest and highest iodine concentration from the selected working range (for 2 and $10 \mathrm{mg} / \mathrm{L}$, respectively) was also performed.

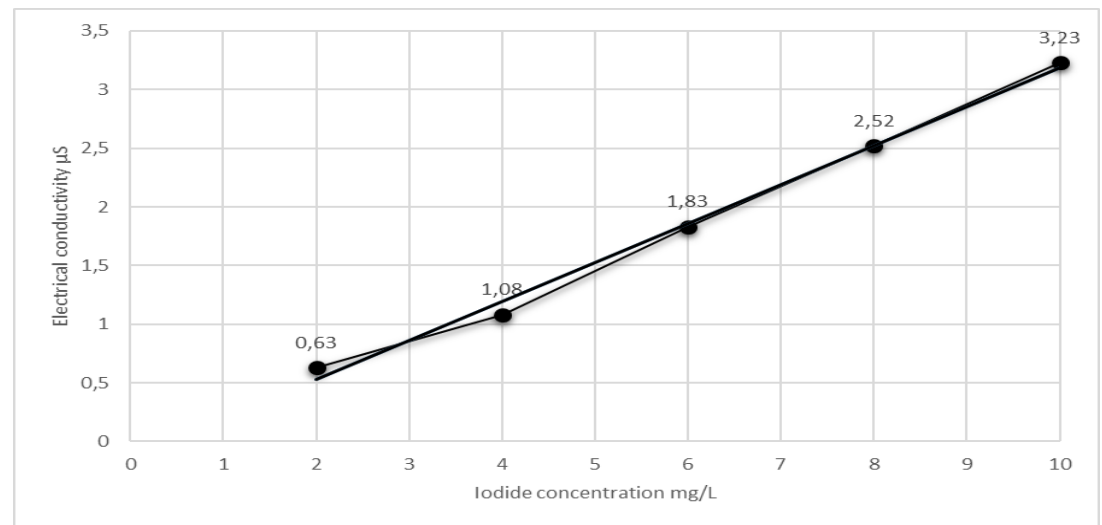

Figure 7. Calibration curve obtained for iodide using IC optimized method

The dispersions were tested using F (Fisher-Snedecor) test. The PG value was calculated and compared with the tabulated values of the distribution $\mathrm{F}(f 1, f 2,1-a)$, where $f 1$ and $f 2$ are the freedom degree and 1- $a$ represents the confidence level. In this particular case, by analyzing 10 results, $f 1$ and $f 2$ were 9 , and the confidence level was chosen to be $99 \%, \mathrm{~F}$ value being 5.35 . If $\mathrm{PG}<\mathrm{F}$, the deviation between the dispersions is not significant, thus the calibration range is correctly chosen. If PG value is higher than $\mathrm{F}(\mathrm{PG}>\mathrm{F})$, the dispersion test is significant and the range was incorrectly selected. The linearity results for the calibration curve and homogeneity of the dispersions are presented in Table 3 where $\left(\mathbf{x}_{\mathbf{i}}\right)$ represents iodine concentration, ( $\left.\mathbf{y}_{\mathbf{i}}\right)$ is the electrical conductivity, (a) is sensitivity, (b) represents the slope, $(\mathbf{R})$ is the correlation coefficient, $\left(\mathbf{S}_{\mathbf{y}}\right)$, and $\left(\mathbf{S}_{\mathbf{x} \mathbf{0}}\right)$ means residual standard deviation and standard deviation, respectively, and $\left(\mathbf{V}_{\mathbf{x} \mathbf{0}}\right)$ is the variance coefficient of the method.

Tabel 3. Liniarity results presented for the optimized method.

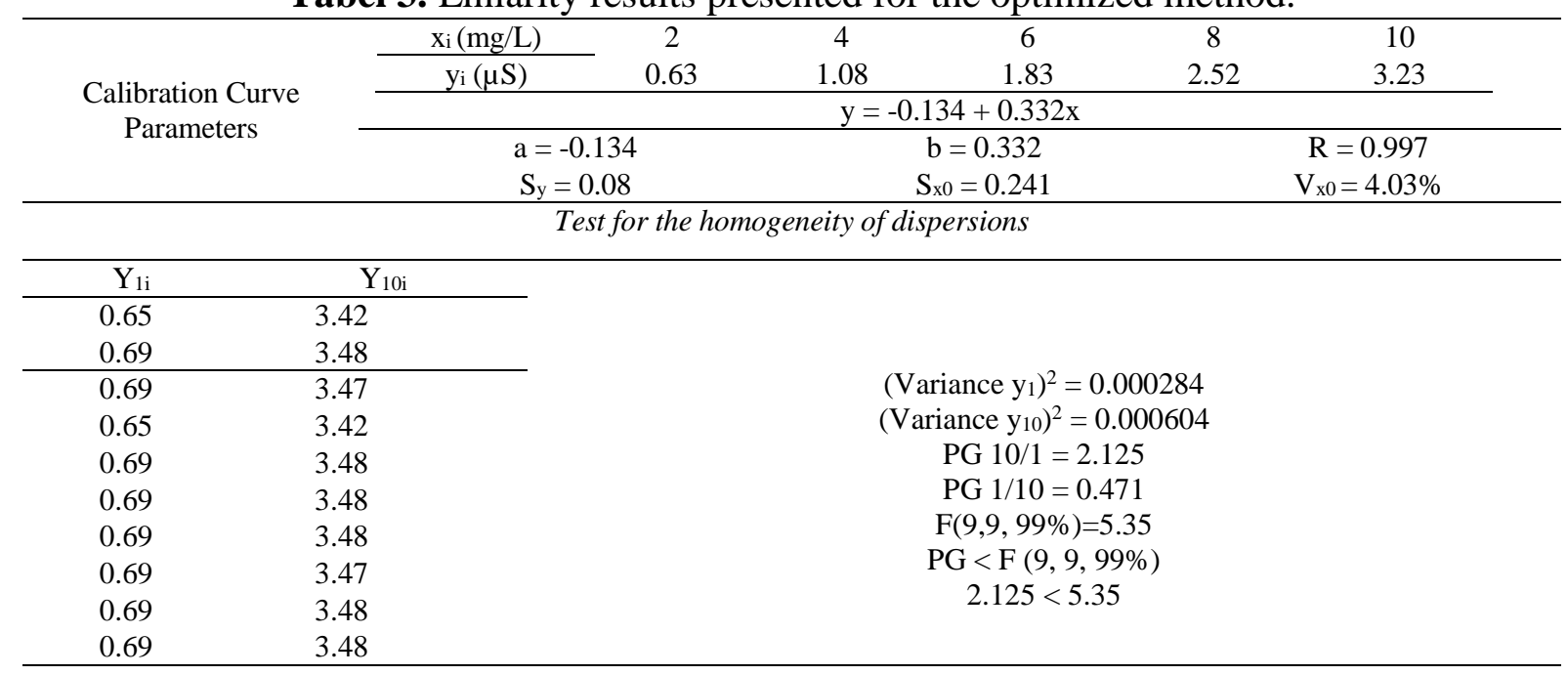

Other performance parameters for the optimized method such as LOD, LOQ, precision, and recovery, could be found in Table 4. Obtained data emphasize that the proposed optimized method is appropriate for the determination of iodine in water sources, the accuracy value being $2.1 \%$ with a recovery of around $98 \%$. 
Table 4. In-house validation experiments.

\begin{tabular}{|c|c|c|c|c|c|}
\hline \multicolumn{6}{|c|}{$L O D, L O Q$ test } \\
\hline \multirow{2}{*}{$\mathrm{X}_{\text {measured }}(\mathrm{mg} / \mathrm{L})$} & 0.672 & 0.688 & 0.686 & 0.670 & 0.649 \\
\hline & 0.647 & 0.645 & 0.646 & 0.726 & 0.670 \\
\hline \multicolumn{2}{|c|}{ LOD (mg/L) } & 0.08 & \multicolumn{2}{|c|}{ LOQ (mg/L) } & 0.26 \\
\hline \multicolumn{6}{|c|}{ Repeatability test } \\
\hline \multirow[t]{2}{*}{$\mathrm{X}_{\text {measured }}(\mathrm{mg} / \mathrm{L})$} & 6.14 & 6.13 & 6.07 & 6.03 & 6.01 \\
\hline & 6.06 & 6.06 & 5.94 & 5.84 & \\
\hline \multirow{2}{*}{\multicolumn{2}{|c|}{$\begin{array}{c}\mathrm{X}_{\text {mean value }}(\mathrm{mg} / \mathrm{L}) \\
\text { Repeatability }(\mathrm{mg} / \mathrm{L})\end{array}$}} & 6.031 & \multicolumn{2}{|c|}{$\mathrm{S}(\mathrm{mg} / \mathrm{L})$} & 0.0936 \\
\hline & & 0.26 & & & 1.55 \\
\hline \multicolumn{6}{|c|}{$\frac{\mathbf{0 . 2 6}}{\text { Intermediate precision test }}$} \\
\hline \multirow[t]{4}{*}{$\mathrm{X}_{\text {measured }}(\mathrm{mg} / \mathrm{L})$} & 6.14 & 6.13 & 6.07 & 6.03 & \multirow[t]{2}{*}{6.01} \\
\hline & 6.06 & 6.06 & 5.94 & 5.84 & \\
\hline & 6.15 & 6.13 & 6.06 & 6.05 & \multirow[t]{2}{*}{6.03} \\
\hline & 6.06 & 6.07 & 5.92 & 5.85 & \\
\hline \multirow{2}{*}{\multicolumn{2}{|c|}{$\begin{array}{c}\mathrm{X}_{\text {mean value }}(\mathrm{mg} / \mathrm{L}) \\
\text { Intermediate precision }(\mathrm{mg} / \mathrm{L})\end{array}$}} & 6.033 & \multirow{2}{*}{\multicolumn{2}{|c|}{$\begin{array}{l}\text { S (mg/L) } \\
\text { RSD }_{\mathrm{R}} \%\end{array}$}} & 0.126 \\
\hline & & 0.35 & & & 2.09 \\
\hline \multicolumn{6}{|c|}{ Recovery test } \\
\hline \multirow{2}{*}{$\begin{array}{c}\text { Initial sample, } X_{1}=2 \\
\mathrm{mg} / \mathrm{L}\end{array}$} & 1.978 & \multicolumn{2}{|c|}{1.980} & 1.976 & 1.945 \\
\hline & 1.979 & \multicolumn{2}{|c|}{1.969} & 2.070 & 1.960 \\
\hline Final sample, & 3.955 & \multicolumn{2}{|c|}{3.950} & 3.967 & 3.970 \\
\hline $\mathrm{X}_{2}=4 \mathrm{mg} / \mathrm{L}$ & 3.917 & & 3.960 & 3.920 \\
\hline $\mathrm{X}_{1 \text { mean value }}(\mathrm{mg} / \mathrm{L})$ & 1.982 & \multicolumn{2}{|c|}{$\frac{3.891}{\mathbf{X}_{2} \text { mean value }}$} & $\eta(\%)$ & 97.96 \\
\hline
\end{tabular}

\subsection{The selectivity of the method, interference studies}

The study of potential interferences is crucial in the validation process, as the presence of other elements in the water sources may influence the results of the analysis. Taking into account the separation column type, the abundance and frequency of the potential interactions, the following anions were studied: fluoride, chloride, sulfate, thiocyanate, thiosulphate, and carbonate.

\section{-Fluoride, chloride, sulfate and thiocyanate influences on iodide determination}

To investigate the influence of the mentioned above anions (excepting thiosulfate and carbonate), on iodide analysis, different concentrations of these anions were tested for the same concentration of iodide solution. The experimental data obtained from the performed tests are presented in Table 5.

Table 5. Recovery percentage for iodide in interference tests (I).

\begin{tabular}{|c|c|c|c|}
\hline \multirow[t]{2}{*}{ Fluoride concentration $(\mathrm{mg} / \mathrm{L})$} & \multicolumn{2}{|c|}{ Iodide concentration $(\mathrm{mg} / \mathrm{L})$} & \multirow{2}{*}{$\begin{array}{c}\text { Recovery yield } \\
(\%)\end{array}$} \\
\hline & Added & Recovered & \\
\hline 0 & 6.009 & 5.91 & 98.4 \\
\hline 3 & 6.009 & 6.02 & 100.2 \\
\hline 10 & 6.009 & 6.23 & 103.7 \\
\hline 15 & 6.009 & 6.22 & 103.5 \\
\hline \multirow[t]{2}{*}{ Chloride concentration $(\mathrm{mg} / \mathrm{L})$} & \multicolumn{2}{|c|}{ Iodide concentration $(\mathrm{mg} / \mathrm{L})$} & Recovery yield \\
\hline & Added & Recovered & $(\%)$ \\
\hline 10 & 5.91 & 5.95 & 100.7 \\
\hline 40 & 5.91 & 5.76 & 97.5 \\
\hline 80 & 5.91 & 5.57 & 94.2 \\
\hline \multirow[t]{2}{*}{ Sulfate concentration $(\mathrm{mg} / \mathrm{L})$} & \multicolumn{2}{|c|}{ Iodide concentration (mg/L) } & \multirow{2}{*}{$\begin{array}{c}\text { Recovery yield } \\
(\%)\end{array}$} \\
\hline & Added & Recovered & \\
\hline 10 & 9.96 & 9.46 & 94.97 \\
\hline 50 & 9.96 & 9.67 & 97.1 \\
\hline 100 & 9.96 & 9.41 & 94.47 \\
\hline Thiocyanate & \multicolumn{2}{|c|}{ Iodide concentration (mg/L) } & Recovery yield \\
\hline concentration $(\mathrm{mg} / \mathrm{L})$ & Added & Recovered & $(\%)$ \\
\hline 10 & 10.07 & 9.12 & 90.06 \\
\hline 25 & 10.07 & 9.12 & 90.06 \\
\hline 50 & 10.07 & 9.43 & 93.64 \\
\hline
\end{tabular}


These results indicate that fluoride concentration up to $15 \mathrm{mg} / \mathrm{L}$, chloride values less than $80 \mathrm{mg} / \mathrm{L}$, sulfate anions up to $100 \mathrm{mg} / \mathrm{L}$, and thiocyanate values less than $50 \mathrm{mg} / \mathrm{L}$ does not influence the determination of iodide using ion chromatography technique. The highest recovery percentage was obtained in the case of fluoride, chloride, and sulfate anions addition (> $94 \%)$.

\section{- Thiosulfate and carbonate influence on iodide analysis}

Unfortunately, the results indicated that the presence of thiosulfate and carbonate compounds in water samples has an important influence on iodide determination, as can be seen in Table 6 .

Table 6. Recovery percentage for iodide in interference tests (II).

\begin{tabular}{|c|c|c|c|}
\hline \multirow{2}{*}{$\begin{array}{c}\text { Thiosulfate } \\
\text { concentration }(\mathrm{mg} / \mathrm{L})\end{array}$} & \multicolumn{2}{|c|}{ Iodide concentration $(\mathrm{mg} / \mathrm{L})$} & \multirow[t]{2}{*}{ Recovery yield (\%) } \\
\hline & Added & Recovered & \\
\hline 10 & 9.88 & 9.36 & 94.74 \\
\hline 25 & 9.88 & 8.27 & 83.7 \\
\hline 50 & 9.88 & 81.27 & 822.6 \\
\hline \multirow{2}{*}{$\begin{array}{c}\text { Carbonate } \\
\text { concentration }(\mathrm{mg} / \mathrm{L})\end{array}$} & \multicolumn{2}{|c|}{ Iodide concentration $(\mathrm{mg} / \mathrm{L})$} & Recovery yield (\%) \\
\hline & Added & Recovered & \\
\hline 10 & 9.98 & 8.13 & 81.46 \\
\hline 30 & 9.98 & 8.03 & 80.46 \\
\hline 50 & 9.98 & 16 & 161.3 \\
\hline
\end{tabular}

Thiocyanates concentration under $25 \mathrm{mg} / \mathrm{L}$ decrease the recovery rate of iodine, while a concentration of $50 \mathrm{mg} / \mathrm{L}$ conducted to aberrant results. The retention times for thiosulfate and iodide anions are very close, which can cause problems for ion separations at high concentration, the interference effect of thiosulfate being obvious.

In the case of carbonates, a concentration of up to $30 \mathrm{mg} / \mathrm{L}$ determined a low recovery yield of iodine (around 80\%). Inadequate results of the recovery rate were also recorded for higher concentration value $(50 \mathrm{mg} / \mathrm{L})$. The conclusion emerging from these determinations indicates that carbonate has also a high influence in the analysis of iodide anion from water sources. As it was mentioned previously, the developed method was tested on a large number of samples of spring water, drinking water, underground, and surface water, Table 7 and 8 presenting the obtained results.

Table 7. Description of the collected water samples

\begin{tabular}{|c|c|c|c|}
\hline $\begin{array}{c}\begin{array}{c}\text { Sample } \\
\text { code }\end{array} \\
\end{array}$ & Description & $\begin{array}{c}\text { Sample } \\
\text { code }\end{array}$ & Description \\
\hline GTW1 & Geothermal water, Calimanesti, Spring no. 1 & GW1 & Groundwater, Rovinari, F2 point \\
\hline GTW2 & Geothermal water, Calimanesti, Spring no. 2 & GW2 & Groundwater, Rovinari, F3 point \\
\hline GTW3 & Geothermal water, Calimanesti, Spring no. 3 & GW3 & Groundwater, Rovinari, F4 point \\
\hline MW1 & Mineral water, Satu Mare & GW4 & Groundwater, Rovinari, F11 point \\
\hline SW1 & Spring water, San Terra Crystal Spring & GW5 & Groundwater, Deveselu \\
\hline SW2 & Spring water, San Terra Crystal Perle Spring & GW6 & Groundwater, Chiajna, City Hall \\
\hline SW3 & Spring water, Miraqua, F5 source, Mostestea & GW7 & Groundwater, Chiajna, School \\
\hline SW4 & Spring water, Calipso, F3 source, Fratesti & GW8 & Groundwater, Chiajna, Stadium \\
\hline SW5 & Spring water, Calipso & GW9 & Groundwater, district 2, Bucharest \\
\hline SW6 & Spring water, Cristal & GW10 & Groundwater, Fountain North, Sfastofca, Tulcea \\
\hline RW1 & Raw water, Targu Carbunesti & GW11 & Groundwater, F1, Costinesti \\
\hline RW2 & Raw water, Ticleni & GW12 & Groundwater, F2, Costinesti \\
\hline RW3 & Raw water, Tezureni & GW13 & Groundwater, F3, Costinesti \\
\hline RW4 & Raw water, Floresteni, Tulcea & GW14 & Groundwater, F4, Costinesti \\
\hline RW5 & Raw water, Pojogeni, Valea Rea & GW15 & Groundwater, Dragiceni, Olt \\
\hline RW6 & Raw water, Scoarta Capacioasa, Tulcea & GW16 & Groundwater, Celaru, Olt \\
\hline RW7 & Raw water, Scoarta Bobu, Tulcea & GW17 & Groundwater, Ionesti, Valcea \\
\hline RW8 & Raw water, Ticleni & GW18 & Groundwater, F1, Chemical Plant Raureni \\
\hline RW9 & Raw water, Babadag, Tulcea & GW19 & Groundwater, F2, Chemical Plant Raureni \\
\hline RW10 & Raw water, Carcaleu, Tulcea & GW20 & Groundwater, Well Pandele, Dambovita \\
\hline
\end{tabular}


Table 8. Iodide concentration in different types of water

\begin{tabular}{cc|cc|cc}
\hline $\begin{array}{c}\text { Sample } \\
\text { code }\end{array}$ & $\begin{array}{c}\text { Iodide } \\
\text { concentration }(\mathrm{mg} / \mathrm{L})\end{array}$ & $\begin{array}{c}\text { Sample } \\
\text { code }\end{array}$ & $\begin{array}{c}\text { Iodide } \\
\text { concentration }(\mathrm{mg} / \mathrm{L})\end{array}$ & $\begin{array}{c}\text { Sample } \\
\text { code }\end{array}$ & $\begin{array}{c}\text { Iodide } \\
\text { concentration (mg/L) }\end{array}$ \\
\hline GTW1 & 0.38 & GW5 & 0.48 & GW19 & $<0.26$ \\
GTW2 & 3.86 & GW6 & $<0.26$ & GW20 & $<0.26$ \\
GTW3 & 5.29 & GW7 & 10.65 & RW1 & $<0.26$ \\
MW1 & 0.78 & GW8 & 0.87 & RW2 & $<0.26$ \\
SW1 & $<0.26^{*}$ & GW9 & 0.09 & RW3 & $<0.26$ \\
SW2 & $<0.26$ & GW10 & 0.37 & RW4 & $<0.26$ \\
SW3 & 1.25 & GW11 & $<0.26$ & RW5 & $<0.26$ \\
SW4 & 0.76 & GW12 & $<0.26$ & RW6 & $<0.26$ \\
SW5 & $<0.26$ & GW13 & $<0.26$ & RW7 & $<0.26$ \\
SW6 & $<0.26$ & GW14 & $<0.26$ & RW8 & $<0.26$ \\
GW1 & 0.32 & GW15 & $<0.26$ & RW9 & $<0.26$ \\
GW2 & $<0.26$ & GW16 & $<0.26$ & RW10 & $<0.26$ \\
GW3 & $<0.26$ & GW17 & $<0.26$ & & \\
GW4 & $<0.26$ & GW18 & $<0.26$ & \\
\hline \multicolumn{5}{r}{ "LOQ of the optimized method. } &
\end{tabular}

\section{Conclusions}

An optimized ion-chromatography method for the determination of iodides from different types of water sources (surface water, groundwater, spring, and geothermal water) was developed and in-house validated. Several operational parameters such as eluent concentration (mobile phase, $\mathrm{KOH}$ ), the flow rate of the mobile phase, the temperature in the detector chamber, and intensity of the suppressor current were optimized. The selectivity of the proposed method was tested, the influence of other anions (fluoride, chloride, sulfate, thiocyanate, thiosulfate, and carbonate) was also investigated. Meanwhile, fluoride, chloride, sulfate, and thiocyanate anions did not present interferences in iodide analysis, at the tested concentrations, unfortunately, it was shown that thiocyanates, as also carbonates lead to low recovery yields or even incorrect results.

Acknowledgments: All experiments were performed by the National Research and Development Institute for Industrial Ecology -ECOIND, Bucharest.

\section{References}

1.ZIMMERMANN, B.M., The role of iodine in human growth and development, Semin. Cell Dev. Biol., 22(6), 2011, 645-652. https://doi.org/10.1016/j.semcdb.2011.07.009

2.BOUILLON, R., ANTONIO, L., Nutritional rickets: historic overview and plan for worldwide eradication. J. Steroid. Biochem., 198, 2020, 105563. https://doi.org/10.1016/j.jsbmb.2019.105563

3.BURGI, H., Iodine excess, Best Pract. Res. Cl. En., 24, 2010, 107-115.

https://doi:10.1016/j.beem.2009.08.010.

4.FUGE, R., JOHNSON C.C., Iodine and human health, the role of environmental geochemistry and diet, a review, Appl. geochem., 63, 2015, 282-302. http://dx.doi.org/10.1016/j.apgeochem.2015.09.013

5.TENG, W., SHAN, Z., TENG, X., Comprehensive Handbook of Iodine. Effect of an increased iodine intake on thyroid diseases: epidemiological study from China, Preedy, R.V., Burrow, N.G., Watson, R., Elsevier Inc., USA, 2009, 1213-1220. https://doi.org/10.1016/B978-0-12-374135-6.00125-4.

6.GILFEDDER, B.S., ALTHOFF, F., PETRI, M., BIESTER, H., A thermo extraction-UV/VIS spectrophotometric method for total iodine quantification in soils and sediments, Anal. Bioanal. Chem., 389(7-8), 2007, 2323-2329. https://doi.org/10.1007/s00216-007-1621-4

7.HOU, X., Comprehensive Handbook of Iodine, Elsevier Inc., Burlington, USA, 2009, 139-150.

8.SHARMA, N., KARANFIL, T., WESTERHOFF, P., Historical and future needs for geospatial iodide occurrence in surface and groundwater of the United States of America, Environ. Sci. Technol. Lett., 6(7), 2019, 379-388. https://doi.org/10.1021/acs.estlett.9b00278 
9. KAMAVISDAR, A., PATEL, R. M., Flow injection spectrophotometric determination of iodide in environmental samples, Microchim. Acta, 140(1-2), 2002, 119-124.

https://doi.org/10.1007/s00604-002-0901-0

10. HUANG, Z., ZHU, Z., SUBHANI, Q., YAN, W., GUO, W., ZHU, Y., Simultaneous determination of iodide and iodate in povidone iodine solution by ion chromatography with homemade and exchange capacity controllable columns and column-switching technique, J. Chromatogr. A, 1251, 2012, 154159.http://dx.doi.org/10.1016/j.chroma.2012.06.059

11. SANZ RODRIGUES, E., SETIAWAN, A.N., POPE, S., HADDAD, P.R., NESTERENKO, P.N., PAUL, B., A simple and sensitive method for the determination of iodide and iodate in raw, ultraviolet- and ozone-treated aquacultural seawater samples using ion chromatography coupled to an ultraviolet detector, Anal. Methods, 8, 2016, 5587-5595. https://doi.org/10.1039/c6ay01381c

12. MINCA, I., BAJENARU (CIOBANU), I., GURAN, C., JOSCEANU, A. M., ISOPESCU, R.D., Validation of an ion chromatographic method for determination of anions in tea infusion, Rev. Chim., 66(6), 2015, 759-765.

13. BAJENARU (CIOBANU), I., MINCA, I., GURAN, C., JOSCEANU, A. M., BACALUM, F., Validation of an ion chromatographic method for determination of anions in wet depositions, Rev. Chim., 64(11), 2013, 1229-1236.

14. STANASEL, O.D., KRISTMANNDOTTIR, H., GAVRIS, G., STANASEL, I., Interpretation of exploration geochemical data by modelling study and physico-chemical investigation, Rev. Chim., 61(8), 2010, 778-783.

15. DAS, P., GUPTA, M., JAIN, A., VERMA, K. K., Single drop microextraction or solid phase microextraction-gas chromatography-mass spectrometry for the determination of iodine in pharmaceuticals, iodized salt, milk powdre and vegetables involving conversion into 4-iodo- $\mathrm{N}, \mathrm{N}$ dimethylaniline, J. Chromatogr. A, 1023, 2004, 33-39. https://doi.org/10.1016/j.chroma.2003.09.056

16. XU, L., LUO, C., LING, H., TANG, Y., WEN, H., Determination of low bromine (Br) and iodine (I) in water with low- to high-salinity content using ICP-MS, Int. J. Mass. Spectrom., 432, 2018, 52-

58. https://doi.org/10.1016/j.ijms.2018.07.009

17. YEBRA, M.C., BOLLAÍN, M.H., A simple indirect automatic method to determine total iodine in milk products by flame atomic absorption spectrometry, Talanta, 82(2), 2010, 828-833.

https://doi.org/10.1016/j.talanta.2010.05.067

18. NAOZUKA J., MESQUITA SILVA DA VEIGA M.A., OLIVEIRA P.V., DE OLIVEIRA E., Determination of chlorine, bromine and iodine in milk samples by ICP-OES, J. Anal. Atomic Spectrom., 18(8), 2003, 917-921. https://doi.org/10.1039/B303897C

19. JANKOWSKI, K., GIERSZ, J., PAPROCKA, M., Improved determination of iodine by sequential (photo)chemical vapor generation and pneumatic nebulization in the programmable temperature spray chamber and inductively coupled plasma optical emission spectrometry, Microchem. J., 113, 2014, 1722. https://doi.org/10.1016/j.microc.2013.11.006

Manuscript received 26.03.2020 